\title{
Perlindungan Hukum Terhadap Nasabah Kaitannya dengan Lembaga Penjamin Simpanan
}

\author{
Tadevin Switkar Putri ${ }^{1}$
}

1Program Studi Magister Kenotariatan, Fakultas Hukum, Universitas Udayana, ,E-mail: tadevin_switkarputri@yahoo.co.id

\begin{tabular}{l}
\hline Info Artikel \\
\hline Masuk: 23 Mei 2019 \\
Diterima: 4 Juli 2019 \\
Terbit : 21 Juli 2019 \\
\\
Keywords : \\
Legal Protection, \\
Customer,Bank, Deposit \\
Insurance Institution \\
\\
\\
Corresponding Author: \\
Tadevin Switkar Putri. \\
E-mail: \\
tadevin_switkarputri@yahoo.co \\
id \\
DOI : \\
10.24843/AC.2019.v04.02.p.07 \\
Kata kunci: \\
Perlindungan Hukum, \\
Pasabah, Bank, Lembaga \\
\end{tabular}

\begin{abstract}
A relation between customer with the bank is only based on the trust, it was not generally balance because the real understanding note just coming from one side which is only from the bank. This unbalanced risk make their debit at the dissolved bank become a common priority to be given, it is very important to provide a legal protection for customers and this is deemned to be studied further based on the perspective of legal protection for customer. From those explanation there is a blurring norms. This research was reviewed based on normative legal research with a legal approach, conception approach, and analytical provisions. The legal materials are sourced from primary, secondary and tertiary materials. Legal materials are collected using snowball system techniques and analyzing legal materials using description technique and interpretation technique. The purpose of this research is to elaborate on the public to understand the regulation of bank customer protection, and understand about the protection of customer which is not covered by LPS. The result of the study concluded that : there was certainty of way out from the problematic or dissolved bank, namely by completing based on article 6 paragraph (2) of the LPS law, this also resolving the problem of crisis against the economy. To protect the norms to save the consumers in related to heir savins which is not borne by LPS, can be specified in accordance with the fabric of bank norms for consumers save which is based on the agreement and based on non contractual relation.
\end{abstract}


nasabah bank, dan paham tentang perlindungan nasabah yang tak ditanggung LPS. Hasil studi memberi kesimpulan bahwa: adanya kepastian jalan keluar dari bank yang bermasalah maupun gagal yakni dengan menyelesaikan berdasarkan atas Pasal 6 ayat (2) UU LPS serta menyelesaikan masalah krisis terhadap perekonomian. Pengamanan norma-norma kepada konsumen penabung sehubungan tabungannya yang tiada ditanggung LPS bisa dirinci berdasarkan jalinan norma bank kepada konsumen penabung yakni atas dasar jalinan kesepakatan dan berdasarkan hubungan non kontraktual.

\section{Pendahuluan}

Lembaga perbankan merupakan inti dari sistem keuangan di setiap negara, karena bank merupakan rujukan setiap orang, badan usaha, baik swasta maupun milik negara/pemerintah, untuk melakukan transaksi baik dalam bentuk penyimpanan uang, hutang piutang, serta jasa-jasa lainnya yang berhubungan dengan masalah keuangan. ${ }^{1}$ Dapat kita tinjau dari hal yang telah terjadi di Indonesia pada tahun 1998 pada waktu itu Indonesia dihantam krisis moneter diamati berdasarkan dibubarkannya enam belas bank yang berakibat pada jenjang keyakinan bank terhadap institusi bank dan system bank. Dalam upaya menanggulangi krisis ini pemerintah berupaya membuat prosedur pengajian antara lain menyerahkan semua agunan tentang keharusan bank untuk melunasinya, terliput pula tabungan dari setiap konsumen. Kondisi ini disuratkan pada Kepres nomor dua puluh enam tahun seribu sembilan ratus sembilan puluh delapan mengenai agunan kepada keharusan pelunasan bank sentral. Tentang blanket guarantee ini merupakan suatu gagasan tindakan darurat untuk memberikan jaminan pelunasan mengenai komitmen bank, hal ini berlaku hanya beberapa lama dan kemungkinan diberlakukan hanya jika timbul kemelut pada industry perbankan. ${ }^{2}$

Pada tahun 1998 pemerintah mengeluarkan kebijakan untuk memberikan jaminan atas seluruh kewajiban pembayaran bank umum (blanket guarantee).Badan Penyehatan Perbankan Nasional (BPPN) kemudian dibentuk pemerintah guna melakukan penyehatan perbankan, penyelesaian aset bermasalah, dan mengupayakan pengembalian uang negara yang tersalur pada sektor perbankan. Dengan kebijakan blanket guarantee ini, pemerintah menjamin pembayaran terhadap seluruh kewajiban bank termasuk pembayaran simpanan masyarakat di bank jika suatu bank dilikuidasi. ${ }^{3}$ Kebijakan blanket guarantee di satu sisi dapat dikatakan berhasil untuk meningkatkan kepercayaan masyarakat terhadap perbankan namun timbulnya moral hazard dari pihak yang terkait di dalamnya maka dipertimbangkannya dengan tujuan menstabilkan system perbankan maka blanket guarantee diakhiri pada tahun 2005. Dalam hal ini satu usaha penjamin simpanan tetaplah diperhatikan oleh pemerintah dengan meningkatkan kepercayaan masyarakat dan meminimumkan resiko yang

1 Mansyur, M. A. (2011). Aspek Hukum Perbankan Syariah dan Implementasinya di Indonesia. Jurnal Dinamika Hukum, 11, 67-75, hal. 67

2 STEPHANI, J. Analisis Hukum Peranan Lembaga Penjamin Simpanan Dalam Melindungi Nasabah Bank. Legal Opinion, 1(4), hal.1

${ }^{3}$ Mamuaja, J. (2015). FUNGSI LEMBAGA PENJAMIN SIMPANAN DALAM RANGKA PERLINDUNGAN HUKUM BAGI NASABAH PERBANKAN DI INDONESIA. Lex Privatum, 3(1), hal.39 
dapat membebani anggaran negara oleh timbulnya moral hazard. Atas dasar undangundang LPS, penanggungan tabungan konsumen akan diselenggarakan bagi LPS. Berlangsungnya ketentuan institusi ini otomatis dimulainya risalah aktual dari penanggungan tabungan konsumen juga pernyataan bank bagi LPS selaku satu institusi yang otonom. Terpaut mengenai pengamalan kegunaan penanggungan tabungan, intitusi ini membuat pelunasan penanggungan pada konsumen penanggungan dari bank yang sudah tidak memiliki izin sejauh sudah terpenuhinya prasyarat yang sudah ditentukan oleh peraturan institusi.

Dalam laju ekonomi di negeri ini bank adalah institusi yang diyakini. Adanya institusi finansial pada suatu teknik ekonomi juga keuangan menjadi hal penting terutama yang ada kaitannya dengan permodalan maupun perputaran uang. Seluruh bank diharuskan memberi jaminan pada dana nasabah yang disimpannya. Berdasar atas hal ini maka hubungan antara nasabah dengan bank hanyalah berdasarkan atas kepercayaan. Sebagian daya upaya untuk menaikkan derajat keyakinan orang kepada bank ialah melalui dipersembahkannya satu kejelasan aturan dalam mengatur dan mengawasi bank juga penanggungan tabungan. Dimana penetapan itu diberlakukan dengan tujuan untuk memihak banyak orang sampai akhirnya semua orang tersebut bisa mempercayai jika uang yang ia taruh atau dengan kata lain disimpan pada bank yang dipercayai tidak akan hilang. Untuk memberi perlindungan hukum pada nasabah dalam hal ini dipandang perlu oleh pemerintah untuk membuat institusi penanggung tabungan. Institusi disini dimaksudkan berdiri secara otonom, terbuka, juga terpandang dalam pelaksanaan fungsi dan otoritasnya untuk dapat dipertanggung jawabkan kepada presiden.

Seluruh kondisi ini memberi dampak pada system keamanan finansial dalam negeri juga situasi ini mampu menjelma prasyarat intimidasi bagi system finansial yang ada di semua belahan negeri, khususnya saat system bank merasakan suatu desakan, yang menjadi vital dalam usaha pemerintah untuk menjaga perekonomian nasional ialah kepercayaan masyarakat. Adapun basis yang paling mendasar pada berjalannya system perbankan yakni berdasar atas kepercayaan masyarakat. Seluruhnya bisa kita amati pada bank yang telah berjalan memiliki lebih sedikit modal dibanding asset yang mereka miliki, ini dikarenakan bank merupakan lembaga penengah kelompokkelompok yang mempunyai uang yang lebih yang disebut dengan deposan untuk selanjutnya dapat dipinjamkan pada peminjam dana atau yang biasa disebut dengan debitur. Jika keyakinan ini tak mampu dipelihara bank sebagai perantaranya sehingga bukan saja berdampak negatif pada bank terkait namun dapat menghilangkan keutuhan lembaga yang berada di dalam lingkup perbankan, dengan begitu apabila fungsi lembaga sebagai mobilisasi dana ini hilang atau terhenti fungsinya akan mempengaruhi pertumbuhan ekonomi dikarenakan pertumbuhan ekonomi timbul jika adanya pengerahan uang berproses dengan tepat guna dan realistis. Perubahan system yang signifikan nampak pada skema penjaminan yang dilakukan oleh LPS dengan dihapusnya penanggungan keseluruhan beban bank menjadi penanggungan seadanya.

Perkembangan LPS sejauh ini telah ada beberapa negara maju telah menyelenggarakan institusi penanggungan tabungan. Dimana notabenenya merupakan negara maju, LPS sudah didirikan oleh negara-negara itu jauh sebelum krisis di asia pasifik terjadi. Selain di indonesia di asia yang telah membentuk LPS diawali oleh filipina dan korea yang kemudian diikuti indonesia, malaysia dan juga singapura. Dimana fungsi yang central dari institusi tersebut yakni dengan menanggung tabungan dari konsumen dan ikut sebagai rangka menjaga ataupun 
memelihara stabilnya system perbankan sesuai dengan kewenangannya. ${ }^{4}$ Terpaut mengenai kegunaan institusi ini sebagai penanggung tabungan konsumen di bank, wewenang uang dipunyai institusi ini diantaranya ialah yang pertama, melakukan penetapan dan pemungutan premi penjaminan kedua, melakukan penetapan dan pemungutan kontribusi ketika bank pertama kali menjadi peserta ketiga, mengelola kekayaan dan tanggungan wajib LPS keempat, mengkonstatir data-data yang diperlukan sejauh tak menyerang kerahasiaan bank kelima, menjalankan perbaikan, pengecekan atau memvalidasi catatan, keenam, melakukan penetapan prasyarat, kaidah-kaidah juga ketetapan penuntasan tuntutan, ketujuh, Menjatuhkan sanksi administratif. ${ }^{5}$

Terpaut koneksi orang bank, nasabah menjadi sisi yang lemah, sebagai penabung uang mereka tak menggenggam jaminan dari bank, hal tersebut cuma berdasar atas keyakinan semata. Apalagi jika bank yang dipercayai terlikuidasi para konsumen pun menjadi sisi yang paling lemah dikarenakan pengembalian dana bagi mereka bukanlah penuntutan yang diunggulkan pelunasannya. Mengenai ini bisa kita melihatnya pada peraturan LPS yang menerangkan jika pelunasan komitmen bank pada semua pemberi pinjaman dari hasil penuntutan. Hal yang tidak seimbang antara nasabah dan bank ini terjadi dikarenakan keberlakuan kesepakatan riil yang telah dikerjakan hanya sepihak oleh bank yang bersangkutan, dan oleh karena pembayaran tagihan dana nasabah dari bank yang gagal bukanlah merupakan yang diutamakan maka dianggap perlu pihak nasabah untuk diberi perlindungan hukum.

Berdasar atas pemaparan diatas terjadi kekaburan norma yang berkenaan dengan dibangunnya LPS dianggap perlu dikaji lebih lanjut dari segi perlindungan hukumnya yakni berkenaan dengan "Perlindungan Hukum Terhadap Nasabah Kaitannya Dengan Lembaga Penjamin Simpanan." Berlandaskan kondisi yang dibeberkan diatas, hingga adapun persoalannya yaitu Bagaimanakah pengaturan tentang perlindungan nasabah bank kaitannya dengan lembaga penjamin simpanan? dan Bagaimanakah perlindungan hukum terhadap nasabah penyimpan atas simpanan yang tidak dijamin oleh lembaga penjamin simpanan?.

Pengkajian ini dimaksudkan guna memberi pemahaman tentang peran LPS sebagai pelindung dana nasabah akibat bank gagal serta untuk memahami bentuk hubungan hukum antar LPS dan bank, hal ini juga menjelaskan kedudukan dan peran LPS dalam system perbankan.

\section{Metode Penelitian}

Metode penelitian hukum pada umumnya membagi penelitian atas dua kelompok besar, yaitu metode penelitian hukum normatif dan metode penelitian hukum empiris. Metode penelitian hukum normatif diartikan sebagai sebuah metode penelitian atas aturan-aturan perundangan baik ditinjau dari sudat hirarki perundangundangn (vertikal), maupun hubungan harmoni perundang-undangan (horizontal). Dalam penelitian ini digunakan penelitian hukum normatif dimana sesuai dengan pendapat peter Mahmud marzuki yaitu untuk memperoleh suatu doktrin-doktrin untuk

\footnotetext{
${ }^{4}$ Mamuaja, J. (2015). FUNGSI LEMBAGA PENJAMIN SIMPANAN DALAM RANGKA PERLINDUNGAN HUKUM BAGI NASABAH PERBANKAN DI INDONESIA. Lex Privatum, 3(1), hal.43

${ }^{5}$ Ibid, hal.45
} 
mengkaji suatu permasalahan hukum yang terjadi. ${ }^{6}$ Pendekatan permasalahan yang dipakai pada pengkajian saat ini ialah ketetapan perundangan, ketetapan konsepsi, dan ketetapan analitis (analitcal approach). Jenis dan bahan sumber hukumnya didapatkan melalui subjek hukum primair bercorak perundangan dan subjek hukum sekunder yang diperoleh melalui artikulasi/bacaan, pendapat sarjana yang bersinggungan bersama pengkajian ini, dan juga subjek norma tertier yang berupa subjek-subjek norma bersumber dari majalah, koran, makalah seminar, kamus-kamus hukum, kamus-kamus ekonomi, kamus-kamus perbankan juga asal-asal lainnya yang terpaut tentang persoalan yang diteliti. Adapun proses kalkulasi bahan hukum pada penelitian ini ialah memakai study kepustakaan (library research) yang selanjutnya diinventarisasi dan dianalisis, baik hukum primer, hukum sekunder ataupun bahan hukum tersier, yang berkaitan dengan inti permasalahan/pokok pikiran fundamental guna menjadi petunjuk kajian. Teknik analisis bahan hukum menggunakan teknik deskriptif.

\section{Hasil dan Pembahasan}

\subsection{Pengaturan Tentang Perlindungan Nasabah Bank Kaitannya Dengan Lembaga Penjamin Simpanan}

Fungsi bank sebagai salah satu dari beberapa lembaga keuangan yang ada di Indonesia yaitu sebagai lembaga intermediasi bagi pihak dengan likuiditas yang dimiliki berlebih baik dalam dunia usaha, instansi pemerintah maupun kelompok rumah tangga dengan pihak lain yang likuiditasnya kurang. Peran ini menyebabkan bank memiliki posisi yang penting dalam mendukung kegiatan ekonomi masyarakat. Bank memiliki fungsi utama sebagai penghimpun serta penyalur dana masyarakat dan memiliki tujuan untuk menunjang pembangunan nasional sebagai bentuk usaha meningkatkan pemerataan ekonomi dan peningkatan kesejahteraan rakyat.7 Dengan menjalankan mekanisme ini bank melancarkan system pembayaran di semua sektor perekonomian. Menurut norma perundangan republik indonesia bank ialah satu institusi guna menghimpunkan uang rakyat banyak kemudian menyalurkannya kembali kepada rakyat sebagai kredit ataupun jasa-jasa lain untuk mengangkat derajat kehidupan banyak orang.

nasabah adalah "konsumen-konsumen sebagai penyedia dana", sedangkan pengertian nasabah menurut Kamus Besar Bahasa Indonesia (1997: 683) adalah orang yang biasa berhubungan dengan atau menjadi pelanggan bank (dalam hal keuangan), nasabah juga dapat diartikan sebagai penyimpan juga merupakan pihak yang menaruh uang di bank sebagai simpanan yang berdasar atas perjanjian antar bank dan nasabah. ${ }^{8}$ Sementara yang dimaksud debitur ialah pihak yang difasilitasi kredit maupun pembiayaan yang lain berdasar prinsip syariah atau yang disetarakan dengan hal tersebut berdasar atas perjanjian bank dan nasabah debitur. Dalam rangka menambah tingkat percaya masyarakat baik yang berkaitan dengan pendanaan maupun kegiatan bank yang lainnya jadi negara menerapkan system penjaminan simpanan yang ditentukan secara eksplisit.

6 Laurensius Arliman, S. (2018). Peranan Metodologi Penelitian Hukum di Dalam Perkembangan Ilmu Hukum di Indonesia. Jurnal Soumatera Law Review, 1(1), hal.118

7 Juniawan, K. (2013). Perlindungan Hukum Terhadap Nasabah Korban Kejahatan Penggandaan Kartu ATM Pada Bank Swasta Nasional di Denpasar. Jurnal Magister Hukum Udayana (Udayana Master Law Journal), 2(2), hal.1

${ }^{8}$ Yupitri, E., \& Sari, R. L. (2012). Analisis Faktor-Faktor yang Mempengaruhi Non Muslim Menjadi Nasabah Bank Syariah Mandiri di Medan (Vol. 1). University of North Sumatra, hal.50 
LPS berawal dari digagasnya UU perbankan dimana dalam Pasal 37b ayat (2) menggagaskan dibentuknya institusi penanggung tabungan. Di luar dari fungsinya yang telah dipaparkan diatas LPS juga turut serta dalam memelihara stabilnya system perbankan sesuai wewenangnya sebagaimana diatur dalam mengadakan penuntasan juga pemecahan terhadap bank gagal melalui wewenangnya dalam pengambil alihan juga merealisasikan semua kedaulatannya, penguasaan juga pengelolaan asset, menelaah kembali atau merubah perjanjian yang membuat bank gagal terikat untuk diselamatkan oleh pihak ketiga yang merugikan bank. ${ }^{9}$

Berdasarkan ketentuan diatas dapat dilihat, bahwa wewenang dari LPS cukup luas untuk menyelesaikan bank bermasalah, lembaga penjamin simpanan memberi jaminan pada uang konsumen berbentuk deposit, lisensi deposit, maupun corak lainnya yang setara mengenai hal tersebut, diterangkan juga seluruh bank yang melaksanakan usahanya pada bagian negeri republik indonesia hendaklah menjabat sebagai partisipan penanggungan. Maka yang menjadi tugas central LPS merupakan menjamin simpanan nasabah. ${ }^{10}$

Berkenaan dengan besarnya kuantiti pinjaman ditentukan jika dana tabungan di bank normal yang terjamin meliputi deposit, lisensi deposit, maupun corak lain guna disetarakannya hal itu. Bukan saja penyimpanan di bank konvensional namun simpanan seperti prinsip syariah pun diberikan jaminan oleh LPS mengenai besaran saldo yang mendapat penanggungan bagi semua konsumen terbanyak sejumlah dua miliar rupiah. Berkenaan dengan saldo simpanan yaitu: "jumlah simpanan yang diberikan jaminan bagi seluruh konsumen di setiap bank pada awalnya hanya terbanyak seratus juta berdasar atas penetapan pemerintah diganti jadi terbanyak dua miliar rupiah. ${ }^{11}$

Fungsi LPS adalah menjamin simpanan nasabah penyimpanan dan turut aktif dalam memelihara stabilitas system perbankan sesuai dengan kewenangannya. 12 fungsi penjaminan diwujudkan dengan melakukan pembayaran klaim penjaminan atas simpanan nasabah bank yang dicabut izinnya dan menunjuk tim likuidasi untuk membereskan aset dan kewajiban bank tersebut, sedangkan fungsi berikutnya adalah turut aktif memelihara stabilitas system perbankan yang diwujudkan dalam bentuk upaya penyelamatan atau penyehatan bank gagal yang tidak berdampak sistematik maupun bank gagal yang berdampak sistemik (bank resolution). ${ }^{12}$

LPS juga berguna untuk menata keselamatan sehatnya bank keseluruhan, berkedudukan selaku pengamat neraca, adanya LPS dianggap sangatlah vital dalam system perbankan untuk mengatasi kepanikan nasabah dan menumbuhkan rasa percaya yang lebih dengan meyakinkan bahwa simpanan mereka aman meskipun keadaan keuangan bank terpuruk. Pengawasan maupun pengaturan ini dirasa penting untuk menekan jumlah resiko yang diambil pihak bank, karena jika hal ini tidak terlaksanakan dengan baik dapat mengganggu stabilnya system keuangan secara menyeluruh. Maka hadirnya LPS dapat mengurangi resiko tersebut secara sistemik dengan pengawasan dan pengaturan yang dilakukan sesuai dengan kewenangannya. Tidak dapat dipungkiri bahwa berjalannya LPS akan jadi lebih baik apabila ditunjang

\footnotetext{
${ }^{9}$ Sentosa Sembiring, 2012, Hukum Perbankan Edisi Revisi, CV. Mandar Maju, Bandung, hal.243.

${ }_{10} \mathrm{Ibid}$.

11 Rohman, M. M. Lembaga penjamin simpanan syariah, hal.195

12 NUGROHO, A. A., \& Sugianto, S. (2017). KAJIAN HUKUM MENGENAI PERAN DAN

FUNGSI LEMBAGA PENJAMIN SIMPANAN DALAM MENJAMIN SIMPANAN NASABAH PERBANKAN. Jurnal Yuridis, 2(2), 231-238, hal.244
} 
dengan system perbankan yang baik hal ini dapat bersinergi dan berjalan bersama untuk menjaga stabilitas system keuangan suatu negara.

\subsection{Perlindungan Hukum Terhadap Nasabah Atas Simpanannya yang Tidak Dijamin Oleh Lembaga Penjamin Simpanan}

Penetapan LPS mengharuskan segenap bank yang berproses di negeri ini agar ikut bersinergi sebagai bagian dari penjamin simpanan, maka dengan hal itu kewajiban untuk menjamin simpanan yang awalnya dibayarkan bank melalui premi pada LPS akan dialihkan sebagai kewajiban LPS untuk menjamin simpanannya ketika bank tersebut gagal. jumlah dana yang sanggup ditanggungkan bagi para konsumen di satu bank terbanyak seratus juta akan tetapi semenjak tiga belas oktober dua ribu delapan jumlah dana penabungan yang mendapat penanggungan ialah sejumlah dua miliar, oleh sebab itu dana yang disimpan nasabah lebih dari dua miliar tak akan mendapatkan jaminan oleh penetapan LPS.

Pemahaman penanggungan ialah ditanggungnya/dipenuhinya janji untuk pemenuhan kewajiban kepada orang lain yang sudah membuat sebuah perjanjian jika perjanjian itu diingkari, oleh karena itu tidak dijamin artinya tidak mendapat tanggungan dan tidak terpenuhinya kewajiban pihak lain yang membuat suatu perjanjian jika tidak dipenuhinya suatu perjanjian tersebut. Atas penjelasan ini, undang-undang LPS tidak menjamin dana yang dimiliki oleh nasabah memiliki pengertian bahwa dana itu tidak memperoleh tanggungan LPS, oleh karenanya timbul lah sebuah hal yang dipertanyakan bagaimanakah perlindungan hukumnya apabila dana yang dimiliki oleh nasabah tidak mendapatkan penjaminan oleh undang-undang LPS. Berdasarkan alasan inilah maka perlu dikaji untuk memperoleh jawaban tentang perlindungan bagi nasabah yang menyimpan dana nya tetapi tidak mendapatkan jaminan oleh LPS.

Adanya beberapa tempat bagi bank untuk mengumpulkan dana, antara lain nya dari tabungan yang mempunyai tugas sebagai pelaksana semua kegiatan operasional bank. Sumber ini adalah sumber yang dana yang lumayan besar untuk bank dan juga sangat memiliki pengaruh yang signifikan terhadap bank, ${ }^{13}$ oleh karenanya, penawaran pelayanan jasa perbankan harus terus dilakukan dengan inovasi yang baru guna untuk mendapat dana dari masyarakat. Semua nasabah harus diberikan kepercayaan oleh bank karena sebuah kepercayaan adalah hal yang sangat penting artinya dari sebuah perbankan. Hermansyah menjelaskan lebih dalam mengenai hal diatas yaitu dimana sangat bergantungnya sebuah perbankan terhadap rasa percaya yang dimiliki masyarakat, maka darinya bank tidak akan bisa menjalankan aktivitas usahanya dengan sempurna tanpa mendapatkan rasa percaya dari masyarakat, maka seluruh pihak perbankan seharusnya bisa memberi sebuah perlindungan hukum kepada kepentingan masyarakat guna untuk bank itu sendiri yaitu supaya mendapat kepercayaan dari masyarakat. Jadi untuk mengantisipasi minimnya rasa percaya masyarakat kepada bank maka sekarang ini bank menggalangkan pengembangan dalam mendapatkan nasabah, yang sangat perlu dilakukan untuk hal itu adalah dengan cara menganugerahkan pengamanan hukum untuk konsumen dalam menyimpan uangnya di bank jika suatu saat bisa terjadi kerugian. ${ }^{14}$

\footnotetext{
${ }^{13}$ Astuti, T., \& Mustikawati, R. I. (2013). Pengaruh Persepsi Nasabah Tentang Tingkat Suku Bunga, Promosi dan Kualitas Pelayanan terhadap Minat Menabung Nasabah. Nominal, Barometer Riset Akuntansi dan Manajemen, 2(1), hal.183-184.

${ }^{14}$ Hermansyah, 2006, Hukum Perbankan Nasional Indonesia, Kencana, Jakarta, hal. 132
} 
Harapan terbesar yang dimiliki masyarakat kepada bank adalah sebuah bank yang pasti memberikan keamanan untuk nasabah menaruh dana nya di sana, masyarakat tidak akan tertarik dengan bunga yang tinggi tetapi juga mempunyai risiko yang besar untuk menaruh dananya. Untuk memprotek hak nasabah maka sangat perlu adanya kepastian hukum yang diberikan untuk konsumen yang sudah menyimpan uangnya di bank. Apabila sudah adanya kepastian itu maka tidak berlebihan kita katakan kalau masyarakat yang mempunyai uang yang lebih banyak akan mau untuk menyimpan uangnya di bank. Sebagai lembaga intermediasi, tugas utama perbankan secara umum adalah menghimpun dana dan menyalurkan dana kepada masyarakat yang kekurangan dana untuk pembiayaan investasi. Dalam hal ini, tingkat kepercayaan yang dimiliki masyarakat dan pihak bank harus terjadi, karena dapat memperlancar jalannya kegiatan perbankan, sehingga bank merasa bertanggungjawab jika terjadi sesuatu hal yang tidak diinginkan. ${ }^{15}$ Dalam penelitian ini mengartikan perlindungan hukum sesuai dengan apa yang sulistyan dari katakan yaitu keadilan harus dianugerahkan bagi hukum untuk seseorang tentang diberikannya dan diaturnya hak dan kewajiban juga keadilan wajib diberikan bagi seseorang itu untuk mendapat kepatutan atas pelanggaran hak dan subjek hukum yang mempertahankan haknya itu. Pengertian yang diberikan oleh nicolai tentang hak dan kewajiban adalah mengandung pengertian bahwa hak memiliki sebuah artian dimana kita bebas dalam mengamalkan/tak mengamalkan suatu hal atau bagi orang lainnya untuk berbuat suatu perbuatan tertentu, sedang suatu kewajiban memiliki kepatutan untuk berbuat atau tidak berbuat suatu perbuatan tertentu. ${ }^{16}$

Sulistyandari juga menerangkan bila ikatan hukum terhadap konsumen yang menabung dananya pada bank adalah sebuah ikatan kontrak dan ikatan yang bukan kontrak. Ikatan kontrak timbul dengan adanya perjanjian terlebih dulu yang sering kita sebut dengan perjanjian simpanan sedang ikatan yang bukan kontrak timbul tidak karena adanya kontrak terlebih dahulu tetapi ikatan itu ada karena adanya pengaturan secara tertulis yang dikeluarkan undang-undang atau hukum kebiasaan dalan sebuah bank telah mengatur hal itu. Jadi ikatan yang kita maksud dalam bahasan ini adalah ikatan secara kontrak dan ikatan yang bukan kontrak.

Anggapan ini menggarisbawahi bahasannya perlindungan hukum tidak cuma bisa kita lihat sebagai cara yang hukum berikan dalam aturan perundangan saja tetapi dapat juga diberikan melalui sebuah kontrak yang telah disepakati seluruh faksi dimaksudkan disini ialah nasabah dan bank. Dimana jika adanya salah satu memungkiri hak dan kewajiban yang terdapat dalam kontrak yang telah disepakati maka sebagai subjek hukum wajib mendapatkan perlindungan hukum atas pelanggaran yang terjadi tersebut. Ini adalah bentuk kestabilan dari ikatan antara nasabah dengan bank yaitu ikatan kontrak dan ikatan yang bukan kontrak. Dalam ikatan kontrak, jalinan hukum bank dan nasabah yang menyimpan dana berdasarkan atas perjanjian menyimpan yang memunculkan perikatan diantara keduanya sehingga mendatangkan hak dan kewajiban, dimana pengembalian simpanan nasabah berikut bungannya seperti yang sudah disepakati merupakan kewajiban bank, kewajiban bank ini yang juga dapat diartikan sebagai hak daripada nasabah untuk mendapatkan pengembalian juga berikut bunganya.

15 Julianto, A. (2012). Analisis Camels Dalam Memprediksi Tingkat Kesehatan Bank Yang Terdaftar Di Bursa Efek Indonesia Periode Tahun 2009-2011. MEDIA, 19(1), hal.40

16 Sulistyandari, 2012, Hukum Perbankan: Perlindugan Hukum terhadap Nasabah Melalui Pengawasan Perbankan di Indonesia, Laros, Sidoarjo, hal. 283 
Secara komunal dan jika meneladani hukum perdata Indonesia kontrak dapat diartikan sebagai satu perihal bilamana sejumlah orang berikrar terhadap orang lainnya/seluruh pihak berikrar guna melakoni sesuatu oleh sebab itu kontrak tersebut akan berjalan sebagai undang-undang untuk pihak yang sudah saling mengikrarkan dirinya, juga akan menimbulkan yang namanya perikatan diantara kedua pihak yang membuatnya. Bentuk perikatan itu berupa satu rentetan ucapan yang memiliki komitmen dan kesanggupan yang diucap atau secara tertulis. ${ }^{17}$ Dalam sebuah ikatan yang bukan kontrak, yang menjadi pengikat diantara seluruh faksi dimaksud disini ialah konsumen juga bank adalah hukum tertulis atau peraturan perundangan, yang memuat pengertian jika perikatan itu timbul sebagai akibat dari jalinan diantara bank dengan nasabahnya, dengan seperti itu maka timbulnya hak dan kewajibanpun atas dasar undang-undang, disini berarti dijaminnya dana nasabah adalah kewajiban bank dengan maksud untuk mengembalikan uang yang disimpan nasabah apapun yang akan terjadi pada bank tersebut.

Penelitian ini akan membahas perihal pengamanan norma konsumen untuk menyimpan uangnya di institusi bank yang tak memperoleh penjaminan oleh LPS, jadi yang akan dijelaskan lebih dulu tentang perlindungan nasabah berdasar atas ikatan kontrak dan ikatan yang bukan kontrak. Kedua ikatan kontrak ini akan dijelaskan dengan cara menyangkutpautkan juga dengan menjabarkan tentang deposit konsumen yang tak memperoleh jaminan LPS pada ikatan kontrak juga ikatan yang bukan kontrak. Jika dipantau dari ikatan kontrak maka saat pengembalian simpanan nasabah baru dilunasi setengahnya oleh bank yaitu sebesar dua milyar rupiah dimana cuma sampai batas inilah kewajiban LPS maka sisa dari dua milyar ini akan tetap menjadi tanggung jawab bank untuk mengembalikan sisanya. Seperti yang telah dijabarkan di awal, bahwa jalinan secara hukum antar bank dan nasabah yang menyimpan uang adalah berdasarkan perjanjian simpanan. Hukum perdata menerangkan jika perjanjian simpanan adalah sebuah perjanjian tanpa nama dimana perjanjian ini tidak pernah ada pengaturannya dalam hukum perdaya namun ditemukan pada masyarakat. Penguraian ini sepaham dengan pemikiran Sulistyandari yang menyampaikan bahwa perjanjian simpanan dana ialah perjanjian yang dalam KUH Perdata, KUHD ataupun undang-undang tidak memperoleh pengaturan secara privat atau istimewa, oleh sebab itu semua ketetapan umum sebuah perjanjian di dalam hukum keperdataan berlaku untuk semua perjanjian terliput juga untuk perjanjian simpanan dana. ${ }^{18}$

Kesimpulan mengenai penjabaran diatas adalah perjanjian simpanan dana yang merupakan perjanjian tidak bernama patuh kepada hukum perdata yang merupakan ketetapan umum sebuah perjanjian khususnya pada buku ketiga bab I,II, dan IV mengenai perikatan. Contohnya mengenai dengan cara apa timbul dan hilangnya perikatan, jenis-jenis perikatan dan lain sebagainya. Poin spesifik ada dalam bab V sampai bab XVII berisikan aturan-aturan tentang perjanjian bernama misanya perjanjian yang sudah lazim digunakan dalam masyakarat dan sudah memiliki nama yang istimewa sendiri yaitu perjanjian jual beli, sewa menyewa, pinjam meminjam dan lainnya. Jalinan antar nasabah yang menyimpan dan bank berlandaskan ikatan kontrak, dimana dalam ikatan kontrak ini hak nasabah hadir dari sebuah kontrak menyimpan uang yang telah disetujui oleh bank dan nasabah itu sendiri. Sejalan

\footnotetext{
17 Indiraharti, N. S. (2016). Aspek Keabsahan Perjanjian Dalam Hukum Kontrak (Suatu Perbandingan Antara Indonesia dan Korea Selatan). Jurnal Hukum PRIORIS, 4(1), 15-38, hal.18

18 Sulistyandari, Op.Cit, hal.296
} 
dengan aturan perdata dan aturan perbankan dimana hak nasabah telah diatur dengan tatanan yang benar, namun isi kesepakatan antar bank dan nasabah telah ditetapkan oleh pihak bank misalnya mengenai jumlah besarnya bunga dan jasa untuk melakukan penyimpanan, ongkos-ongkos yang mesti nasabah keluarkan untuk menyimpan uangnya dan lazimnya perjanjian simpanan dana ini ialah perjanjian baku yang lazimnya berisi kebijakan yang lebih memberikan keuntungan kepada pihak bank. ${ }^{19}$

Dengan hal itu maka kedaulatan juga keharusan konsumen penabung ialah persetujuan yang timbul dari permufakatan simpanan uang, makanya apabila bank sudah tidak lagi memiliki izin beroperasi dan hak-hak nasabah baru diberikan setengahnya atau senilai jaminan yang diberikan LPS, sisanya ialah hak dari nasabah untuk memperoleh pelunasan dan ialah tanggung jawab bank untuk melakukan pelunasan sisanya. Apabila bank ingkar dalam pemenuhan tanggung jawabnya sebagaimana yang tertuang dalam kontrak maka bank itu telah melakukan perbuatan wanprestasi yaitu tidak menyanggupi penerapan keharusan yang tak sesuai saat periodenya tiba untuk dikerjakan. Hingga membangkitkan komitmen si konsumen guna menyerahkan, memenuhi kerugian yang ditimbulkannya, atau apabila seluruh faksi ingkar maka faksi lainnya dapat menagih batalnya kesepakatan. Wanprestasi memiliki bentuk-bentuk sebagai berikut yaitu sama sekali tidak melangsungkan prestasi, melangsungkan tetapi tidak tepat waktu, melangsungkan tapi tidak sama seperti yang disepakati dan yang berdasarkan kesepakatan tidak boleh dilakukan tetapi dilakukan oleh debitur. ${ }^{20}$

Berikut ialah beberapa akibat hukum yang akan terjadi terhadap debitur yang melakukan wanprestasi diantaranya ialah pertama, kesepakatan tetap berlangsung kreditur masih mungkin melakukan penuntutan kepada debitur untuk melangsungkan prestasi jikalau ia telat mengabulkan sebuah prestasi. Selain daripada itu kreditur masih memungkinkan meminta ganti rugi yang disebabkan oleh terlambatnya prestasi untuk dipenuhi. Kedua, kreditur memperoleh ganti rugi dari si debitur. Ketiga, berpindahnya beban risiko atas kerugian yang dialami debitur apabila kendala tersebut muncul setelah debitur wanprestasi, kecuali apabila pihak kreditur dengan sengaja melakukan kelalaian yang besar oleh karenanya debitur dapat bebas dari beban dengan berpedoman pada sebuah keadaan yang memaksa. Keempat, apabila perikatan datang dari kesepakatan timbal balik dimana terbebasnya kreditur dari keharusan untuk memberi prestasi dengan berpedoman kepada Kitab Undangundang Hukum Perdata. ${ }^{21}$

Dari penjabaran diatas, banyak hal yang dapat dituntut oleh nasabah sebagai pihak yang menggugat antara lainnya meminta biaya kerugian dan bunga dari simpanannya juga biaya lainnya seperti biaya yang dikeluarkan saat berperkara di pengadilan. Pengertian nasabah tidak memperoleh jaminan dalam ikatan yang bukan kontrak ialah tidak dijaminnya simpanan nasabah oleh LPS. LPS sendiri memiliki keharusan untuk membereskan klaim nasabah terhadap penjaminan oleh bank yang izin

\footnotetext{
${ }^{19}$ Ibid, hal 300

${ }^{20}$ Effendi, P. (2015). KEDUDUKAN PARA PIHAK DALAM PERJANJIAN SATANDAR PERBANKAN DITINJAU DARI KITAB UNDANG-UNDANG HUKUM PERDATA DAN UNDANG-UNDANG NOMOR 8 TAHUN 1999 TENTANG PERLINDUNGAN KONSUMEN. Jurnal Pro Hukum: Jurnal Penelitian Bidang Hukum Universitas Gresik, 4(2), hal. 90

${ }^{21}$ Khair, U. (2017). Analisis Yuridis Perjanjian Pembiayaan Konsumen Dan Akibat Hukum Jika Terjadi Wanprestasi Dalam Perjanjian Pembiayaan Konsumen Di Indonesia. Jurnal Cendekia Hukum, 3(1), 32-45, hal.41
} 
usahanya sudah dicabut. LPS mempunyai sifat keterbatasan atas penanggungan simpanan nasabah bank. Apabila bank bangkrut dan tidak bisa meneruskan usahanya LPS memiliki pertanggungjawaban untuk memberikan pembayaran kepada setiap nasabah yang telah menyimpan uangnya di bank dalam jumlah-jumlah yang telah ditentukan. Apabila ada penyimpanan yang tidak mendapatkan jaminan maka akan dituntaskan dengan cara likuidasi bank. Hal ini terjadi dengan alasan bahwa bank dalam melakukan kegiatannya berdasarkan sebagai kandidat penjamin.

Jaminan yang diberikan atas simpanan yang dilakukan nasabah pada satu bank dengan nilai awal sebesar seratus juta rupiah kini telah berubah menjadi tidak lebih dari dua milyar rupiah. Pertanggungjawaban yang harus dipenuhi oleh LPS yaitu dengan membayar klaim jaminan kepada konsumen yang menaruh uangnya pada bank yang sudah kehilangan izin usahanya. LPS tidak segera melunasi klaim penjaminan kepada nasabah apabila jumlah simpanan nasabah tersebut melewati batas maksimum yang akan diberikan oleh LPS dan juga jika dilihat dari ketentuan yang berlaku klaim tersebut diputuskan tidak layak berdasarkan hasil pengecekan menyeluruh tentang tidak terteranya data simpanan nasabah pada bank, tidak wajarnya keuntungan yang diperoleh nasabah dan apabila nasabah tersebut ialah penyebab dari tidak sehatnya kondisi bank.

Kesimpulan atas pemaparan diatas ialah tidak dijaminnya simpanan nasabah dalam ikatan bukan kontrak atas dasar bahwa simpanan nasabah tersebut lebih dari dua milyar rupiah dan simpanan nasabah itu berdasarkan penilaian menyeluruh terdapat ketidaklayakan untuk memperoleh penjaminan. Berdasarkan pengidentifikasian simpanan nasabah tersebut timbullah sebuah persoalan tentang bagaimana hukum dapat menganugerahkan pengamanan kehadapan konsumen untuk menyimpan uangnya di bank tetapi tidak memperoleh penjaminan atas simpanannya tersebut. Nasabah akan mendapatkan risiko besar apabila bank tempatnya manyimpan uang ditutup karena ada beberapa penggolongan simpanan yang tidak memperoleh jaminan oleh LPS. Jika meneladani peraturan LPS, kegunaan LPS selain melakukan penjaminan juga ikut berperan dalam melakukan pemeliharaan kestabilan system bank, menurut otoritasnya LPS memiliki peran dalam melakukan perumusan dan penetapan prosedur yang ada guna untuk terus giat melakukan pemeliharaan kestabilan system perbankan dan melangsungkan prosedur perihal menyelesaikan bank yang gagal yang tidak berpengaruh secara sistemik. Adapun kedaulatan yang dimiliki oleh LPS ialah dalam pengambil alihan dan mengaplikasikan seluruh hak dan otoritas dari pemegang saham terhitung juga mengenai kedaulatan serta otoritas rapat umum pemegang saham, mengontrol serta menata kekayaan serta kemestian bank gagal yang telah dibebaskan, mengurungkan dan menyelesaikan serta mengalihkan seluruh permufakatan yang membelenggu bank gagal yang sudah terselamatkan dari faksi lainnya yang membawa kerugian, memasarkan kekayaan bank tidak berizin, pertanggungjawaban bank tidak berizin.

Pada Pasal 54 ayat (1) Undang-undang LPS telah mengatur mengenai urutan pembayaran kewajiban bank kepada para kreditur dari hasil pencairan dan/atau penagihan sesuai dengan Pasal 53 Undang-undang LPS, dilakukan dengan urutan sebagai berikut: (1) Penggantian atas talangan pembayaran gaji pegawai yang terutang. (2) Penggantian atas pembayaran talangan pesangon pegawai. (3) Biaya perkara di pengadilan, biaya lelang yang terutang dan biaya operasional kantor. (4) Biaya penyelamatan yang dikeluarkan oleh LPS dan/atau pembayaran atas klaim penjaminan yang harus dibayarkan oleh LPS. (5) Pajak yang terutang. (6) Bagian simpanan dari nasabah penyimpan yang tidak dibayarkan penjaminannya dan 
simpanan dari nasabah penyimpan yang tidak dijamin. (7) Hak dari kreditor lainnya. Pelaksanaan pembayaran kewajiban bank yang dilikuidasi dilakukan oleh bank pembayar yang telah ditunjuk oleh LPS. Berdasarkan pasal di atas dapat diartikan bahwa selain memberikan perlindungan terhadap para nasabah kecil, LPS juga berusaha untuk melindungi para nasabah besar atau bagi mereka yang mempunyai simpanan lebih dari dua miliar pada suatu bank. Pengertiannya adalah nasabah yang memiliki simpanan sampai dua miliar adalah klaim yang harus dibayar oleh LPS ketika bank dicabut izinnya. Bagi nasabah yang simpanannya di atas dua miliar, atau bagi nasabah yang simpanannya tidak dijamin akan dibayarkan setelah pencairan aset bank yang dilikuidasi. Teknisnya adalah dalam hal menyelesaikan proses likuidasi, LPS akan membentuk tim likuidasi, tim likuidasi ini akan menguasai seluruh aset bank gagal. Jika aset bank tersebut dijual, maka hasilnya akan dihitung untuk membayar segala biaya yang berkaitan dengan likuidasi dan tercantum dalam daftar biaya likuidasi, termasuk bagian simpanan dari nasabah penyimpan yang tidak dibayarkan penjaminannya dan simpanan dari nasabah penyimpan yang tidak dijamin, menjadi beban aset bank dalam likuidasi dan dikeluarkan terlebih dahulu dari setiap pencairannya (urutannya sesuai dengan Pasal 54 ayat (1) Undang-undang LPS).22

Penyimpanan tak terjamin oleh LPS ketika hasil penyitaan asset pembubaran bank menjadi urutan keenam dalam penanggungannya. Simpanan yang tidak dijamin dapat mengajukan keberatan pada LPS bagi nasabah yang dirugikan namun harus berdasar bukti nyata dan jelas dengan melalui proses hukum di pengadilan. Berkenaan hal ini pengajuan hukum yang dimaksud dilakukan dengan menuntut ganti rugi karena LPS tidak menuntaskan kewajibannya berdasarkan yang telah diamanatkan dalam undang-undang. Berdasar atas hal ini simpanan yang tidak dijamin atas dasar non kontraktual dapat mengajukan ke pengadilan berdasar dengan gugatan perbuatan melawan hukum.

Usaha hukum yang ditempuh dengan mengajukan ke pengadilan negeri, jika yang melaporkan semata-mata sebagian orang niscaya tidaklah timbul persoalan namun dengan jalan apa bila yang melakukannya lebih dari ratusan orang. Pastinya gugatan yang dimaksudkan hanya pada satu pihak dalam hal ini lembaga menjadi kurang efektif karena mangantongi kemiripan perkara, dan mengantongi landasan penuntutan hukum sama. Dalam hal ini akan menjadi lebih efisien apabila dilakukan gugatan oleh perwakilan dari kelompok. Berdasar atas aturan pemerintah mengenai penetapan tuntutan delegasi fraksi-fraksi yang dinyatakan dengan tuntutan delegasi fraksi-fraksi ialah satu usaha penyajian gugatan, bilamana seorang/banyak orang mengatasnamakan fraksi menggugat demi pribadi atau masing-masing individu dan perwakilan fraksi dengan kuantitas yang berlimpah serta mempunyai persamaan realitas/norma hukum antar perwakilan fraksi serta delegasi fraksi tersebut beserta pengajuan tuntutan melalui delegasi mampu tercapainya sejumlah benefit, antara lain pertama, proses menjadi lebih murah, tidak butuh menggelontorkan biaya berkali lipat mengenai perihal yang setingkat kedua, penetapan hakim yang berlawanan andaikata tuntutan diserahkan secara individual mempu terhindarkan ketiga, eksekutor pengingkar dapat menjadi lebih hati-hati serta diinginkan untuk insaf atas pengingkaran yang setara. Pelaku tidak hanya bersanding dengan sesorang saja tapi

22 Zuriyati, Z., Bachtiar, M., \& Fitriani, R. (2015). Perlindungan Hukum Terhadap Nasabah Penyimpan Dana Pada Bank Yang Dilikuidasi Menurut Undang-undang Nomor 24 Tahun 2004 Tentang Lembaga Penjamin Simpanan. Jurnal Online Mahasiswa Fakultas Hukum Universitas Riau, 2(2), hal.12 
lebih. ${ }^{23}$ Konsumen yang mempunyai kesetaraan kejadian, mempunyai norma-norma serta desakan yang setara dapat melalui perwakilan kelompoknya, perwakilan kelompok tersebut harus memiliki kesamaan peristiwa dengan anggotanya. Tapi tidak tertutup kemungkinan nasabah melakukan guagatan secara individual apalagi mengalami peristiwa, dasar hukum, dan tuntutan yang berbeda.

\section{Kesimpulan}

Berdasarkan Pasal 8 ayat (1) Undang-Undang Nomor 24 Tahun 2004 tentang Lembaga Penjamin Simpanan keseluruhan bank yang berusaha di dalam negeri ini diharuskan untuk menjadi peserta penjaminan. Maka tugas central LPS ialah menjamin simpanan nasabah, kepatutan jalan keluar dari bank-bank bermasalah atau gagal dengan mampu menuntaskan kewajiban sesuai dengan kapasitasnya, dengan jaminan saldo pada setiap nasabah sejumlah dua miliar rupiah. LPS dalam system perbankan dianggap central menjadi lembaga yang meyakinkan nasabah berkenaan simpanannya sekalipun kondisi keuangannya memburuk. Pengamanan hukum pada konsumen yang tak digaransi oleh LPS akan dipenggal berdasar hukum bank dengan nasabah yang berlandaskan hubungan kontraktual, yakni hal yang dimaksud senantiasa menjelma sebagai kedaulatan konsumen serta beban bagi bank untuk menuntaskannya sesuai yang diperjanjikan bila bank tidak melakukan pemenuhannya akan dianggap melakukan wanprestasi, maka nasabah bisa menuntut berdasar atas ketentuan dimaksud, berdasar atas hubungan non kontraktual dimana nilai simpanan yang mencapai dua miliar akan mendapatkan haknya dari hasil pencairan asset bank pada proses likuidasi dengan urutan keenam, perlindungan hukumnya dapat mengajukan keberatan pada LPS atau melakukan upaya hukum lewat pengadilan atas perbuatan melawan hukum. Dengan demikian pemerintah diharapkan tetap mensosialisasikan kepada masyarakat terhadap peraturan yang berkaitan dengan LPS, dan masyarakat disarankan untuk lebih memahami LPS tersebut.

\section{Daftar Pustaka}

\section{Buku}

Hermansyah, 2006, Hukum Perbankan Nasional Indonesia, Kencana, Jakarta.

Krisna Harahap, 2007, Hukum Acara Perdata: Class Action, Arbitrase \& Alternatif serta Mediasi, Cet 5, Bandung:PT. Grafitri Budi Utami.

Sentosa Sembiring, 2012, Hukum Perbankan Edisi Revisi, CV. Mandar Maju, Bandung.

Sulistyandari, 2012, Hukum Perbankan: Perlindugan Hukum terhadap Nasabah Melalui Pengawasan Perbankan di Indonesia, Laros, Sidoarjo.

\section{Jurnal}

Astuti, T., \& Mustikawati, R. I. (2013). Pengaruh Persepsi Nasabah Tentang Tingkat Suku Bunga, Promosi dan Kualitas Pelayanan terhadap Minat Menabung Nasabah. Nominal, Barometer Riset Akuntansi dan Manajemen, 2(1).

Effendi, P. (2015). KEDUDUKAN PARA PIHAK DALAM PERJANJIAN SATANDAR PERBANKAN DITINJAU DARI KITAB UNDANG-UNDANG HUKUM PERDATA DAN UNDANG-UNDANG NOMOR 8 TAHUN 1999 TENTANG

\footnotetext{
${ }^{23}$ Krisna Harahap, 2007, Hukum Acara Perdata: Class Action, Arbitrase \& Alternatif serta Mediasi, Cet 5, Bandung:PT. Grafitri Budi Utami, hal. 36-37
} 
PERLINDUNGAN KONSUMEN. Jurnal Pro Hukum: Jurnal Penelitian Bidang Hukum Universitas Gresik, 4(2).

Indiraharti, N. S. (2016). Aspek Keabsahan Perjanjian Dalam Hukum Kontrak (Suatu Perbandingan Antara Indonesia dan Korea Selatan). Jurnal Hukum PRIORIS, 4(1), 15-38.

Juniawan, K. (2013). Perlindungan Hukum Terhadap Nasabah Korban Kejahatan Penggandaan Kartu ATM Pada Bank Swasta Nasional di Denpasar. Jurnal Magister Hukum Udayana (Udayana Master Law Journal), 2(2).

Julianto, A. (2012). Analisis Camels Dalam Memprediksi Tingkat Kesehatan Bank Yang Terdaftar Di Bursa Efek Indonesia Periode Tahun 2009-2011. MEDIA, 19(1).

Khair, U. (2017). Analisis Yuridis Perjanjian Pembiayaan Konsumen Dan Akibat Hukum Jika Terjadi Wanprestasi Dalam Perjanjian Pembiayaan Konsumen Di Indonesia. Jurnal Cendekia Hukum, 3(1), 32-45.

Laurensius Arliman, S. (2018). Peranan Metodologi Penelitian Hukum di Dalam Perkembangan Ilmu Hukum di Indonesia. Jurnal Soumatera Law Review, 1(1)

Mamuaja, J. (2015). FUNGSI LEMBAGA PENJAMIN SIMPANAN DALAM RANGKA PERLINDUNGAN HUKUM BAGI NASABAH PERBANKAN DI INDONESIA. Lex Privatum, 3(1).

Mansyur, M. A. (2011). Aspek Hukum Perbankan Syariah dan Implementasinya di Indonesia. Jurnal Dinamika Hukum, 11, 67-75.

NUGROHO, A. A., \& Sugianto, S. (2017). KAJIAN HUKUM MENGENAI PERAN DAN FUNGSI LEMBAGA PENJAMIN SIMPANAN DALAM MENJAMIN SIMPANAN NASABAH PERBANKAN. Jurnal Yuridis, 2(2), 231-238.

Rohman, M. M. Lembaga penjamin simpanan syariah.

Yupitri, E., \& Sari, R. L. (2012). Analisis Faktor-Faktor yang Mempengaruhi Non Muslim Menjadi Nasabah Bank Syariah Mandiri di Medan (Vol. 1). University of North Sumatra.

Zuriyati, Z., Bachtiar, M., \& Fitriani, R. (2015). Perlindungan Hukum Terhadap Nasabah Penyimpan Dana Pada Bank Yang Dilikuidasi Menurut Undangundang Nomor 24 Tahun 2004 Tentang Lembaga Penjamin Simpanan. Jurnal Online Mahasiswa Fakultas Hukum Universitas Riau, 2(2).

\section{Peraturan Perundang-undangan}

Kitab Undang-undang Hukum Perdata

Undang-undang Republik Indonesia Nomor 10 Tahun 1998 Tentang Perubahan atas Undang-undang Nomor 7 Tahun 1992 tentang Perbankan

Undang-undang Republik Indonesia Nomor 24 Tahun 2004 tentang Lembaga Penjamin Simpanan 